\title{
Genetic Diversity of Indonesian Swamp Buffalo Based on Microsatellite Markers
}

\author{
F. Saputra ${ }^{\mathrm{a}, *}$, Jakariaa ${ }^{\mathrm{b}}$, A. Anggraeni ${ }^{\mathrm{a}}$, \& C. Sumantri ${ }^{\mathrm{b}}$ \\ ${ }^{a}$ Indonesian Research Institute for Animal Production, Bogor \\ Jalan Veteran III, Bogor 16720, Indonesia \\ ${ }^{b}$ Department of Animal Production and Technology, Faculty of Animal Science, IPB University \\ (Bogor Agricultural University) \\ Jalan Agatis, Kampus IPB Dramaga Bogor 16680, Indonesia \\ ${ }^{*}$ Corresponding author: ferdysaputra@pertanian.go.id; ferdy44saputra@gmail.com \\ (Received 25-10-2019; Revised 14-03-2020; Accepted 16-04-2020)
}

\begin{abstract}
Indonesia has high genetic resources of local swamp buffalo with good adaptation across regions. However, these animals decline in both population and genetic quality. This research was conducted to study the genetic diversity of Indonesian swamp buffalo. A total of 199 DNA samples (swamp buffalo) from seven provincial populations were used in this study. Genetics identification used three microsatellite markers (CSSM66, ILSTS61, and ILSTS17). Microsatellites were visualized by Polyacrylamide Gel Electrophoresis (PAGE) 10\% with silver staining method. Microsatellite data were analyzed using GenAlEx 6.41, Cervus 3.0, and POPTREE2 software. The results showed that a total of 9 alleles were found from the three loci. ILSTS61 had a high PIC (Polymorphism Information Content) compared to the other loci. The high observed heterozygosity of ILSTS61 was found in swamp buffalo from Riau Province, while the Ho value of ILSTS17 ranged from 0.000 to 0.170 . This study identified two clusters for Indonesian swamp buffalo, i.e., cluster I (Aceh, North Sumatra, and Riau) and cluster II (Banten, Central Java, West Nusa Tenggara, and South Sulawesi). The two major divergent directions are considered in Indonesia swamp buffaloes across the observed provinces.
\end{abstract}

Keywords: genetics diversity; Indonesian swamp buffalo; microsatellite

\section{INTRODUCTION}

Animal genetic resources are important parts of genetic materials in supporting food security for human life. Animal genetic resources are also essential raw materials in their sustainable uses for livestock production (Kantanen et al., 2015). Moreover, conservation and sustainable use of animal genetic data are also part of the Food and Agriculture Organization (FAO) program to strengthen the contribution of livestock in maintaining food security and development, and to prevent the loss of animal genetic resources at regional, national, and global levels. Hence, the molecular genetic characterization of livestock is needed, especially for local swamp buffaloes, because genetic information on them is very useful to achieve a complete molecular genetic variability information.

These molecular genetic variabilities become important information for selective breeding programs and conservation programs of local swamp buffaloes in Indonesia. However, selective breeding has limitations on molecular data on the existing local swamp buffalo genetic variation across countries. Previously wide studies on buffalo domestication have been conducted and it was concluded that the origin of buffalo domestication occurred in China (Yue et al., 2013). Microsatellites have been widely used for the study of genetic diversity on various types of livestock in Indonesia such as in cattle
(Abdullah et al., 2012; Agung et al., 2016; Agung et al., 2019), goats (Zein et al., 2012), and sheep (Jakaria et al., 2012). Microsatellite studies in local swamp buffaloes have been reported in Indonesia, but are still limited. Based on previously microsatellite studies, buffaloes from Bogor and Sulawesi have a close relationship with buffalo from Australia (Barker et al., 1997). A study on genetic diversity based on microsatellite has not been conducted especially in Indonesia. This study aims to determine genetic diversity based on microsatellite markers on several swamp buffaloes' populations in Indonesia so that breeding programs can be determined for the future.

\section{MATERIALS AND METHODS}

\section{DNA Samples}

The buffalo DNA samples are a collection of Laboratory of Animal Molecular Genetics, Faculty of Animal Science, IPB University. A total of 199 swamp buffalo DNA samples consisting of populations from Aceh (30), North Sumatra (30), Banten (30), Central Java (30), West Nusa Tenggara (30), South Sulawesi (30), Riau (19), and 12 river buffalo DNA samples from North Sumatra. DNA specimens were collected from 2009-2012. 


\section{PCR Amplification}

A total of 3 microsatellite primers, i.e., CSSM66, ILSTS61, and ILSTS17, were used by Kathiravan et al. (2009). The PCR reagent composition was as follows: DNA samples (25 $\mathrm{ng}$ to $50 \mathrm{ng}$ ) primer; $10 \mathrm{mM}$ dNTPs (Thermo Scientific, USA), $25 \mathrm{mM} \mathrm{MgCl} 2$ (Thermo Scientific, US); 10x Buffer (Thermo Scientific, USA), 5 U/ $\mu$ L Dream-Taq Polymerase (Thermo Scientific, USA), and Nuclease Free Water (Thermo Scientific, USA). The Polymerase Chain Reaction (PCR) program was performed under the following condition: initial denaturing at $94^{\circ} \mathrm{C}$ for $5 \mathrm{~min}$ followed by 30 cycles of $15 \mathrm{~s}$ at $94^{\circ} \mathrm{C}$, $15 \mathrm{~s}$ at $55^{\circ} \mathrm{C}, 15 \mathrm{~s}$ at $72^{\circ} \mathrm{C}$, and a final elongation of $1 \mathrm{~min}$ at $72^{\circ} \mathrm{C}$. The amplicon was visualized by Polyacrylamide Gel Electrophoresis (PAGE) 10\% with silver staining method (Byun et al., 2009).

\section{Data Analysis}

The observed variables were the number of alleles (na), effective alleles (ne), observed heterozygosity values (Ho), expected heterozygosity values $(\mathrm{He})$, were analyzed using GenAlEx 6.41 software (Peakall \& Smouse, 2012). The polymorphism information content (PIC) and Hardy-Weinberg (HW) were obtained from Cervus 3.0 (Kalinowski et al., 2007). Nei genetic distance and dendrogram were obtained from allele frequencies using POPTREE2 software (Takezaki et al., 2010). The dendrogram was generated using the Neighbor-Joining method with bootstrapping 1000 times.

\section{RESULTS}

\section{Microsatellite Variability}

Study on the three microsatellite loci from 7 populations of swamp buffalo in Indonesia identified 9 alleles that consisted of 8 alleles detected in Aceh, 8 alleles in the North Sumatra, 7 alleles in Riau, 8 alleles in Banten, 7 alleles in Central Java, 8 alleles in West Nusa Tenggara, and 8 alleles in South Sulawesi (Table 1). The CSSM66 allele A was found only in Banten, while the ILSTS61 allele A was found in Aceh, North Sumatra, Riau, West Nusa Tenggara, and South Sulawesi.
Microsatellite analysis results showed that the ILSTS61 locus had high heterozygosity values across swamp buffalo populations. The exception was for river buffalo populations in North Sumatra (Table 2). The Hardy-Weinberg results showed the ILSTS61 locus in the populations of Riau, Banten, Central Java, and West Nusa Tenggara was in Hardy-Weinberg equilibrium.

\section{Heterozygosity of Microsatellite}

The observed heterozygosity of three loci values ranged from 0.000 (CSSM66) to 0.620 (ILSTS61) and the expected heterozygosity values ranged from 0.060 (CSMM66) to 0.770 (ILSTS61). The ILSTS61 locus had high $\mathrm{Ho}, \mathrm{He}$, and PIC values from the three loci (Table 3). A high PIC value illustrated the level of identifying information or locus used, which was very informative as a marker (marker). The CSSM66 and ILSTS17 loci had two alleles, compared to the ILSTS61 locus, whereas the CSSM66 and ILSTS17 loci had more repetitive motives than the ILSTS61 locus (Kathiravan et al., 2009).

\section{Genetic Distance}

The result of genetic distance analysis showed that the genetic distance value of Indonesian swamp buffalo ranged from 0.021 to 0.168 (Table 4). Buffalo population from North Sumatra and Riau population had the closest genetic distance compared to the others. In contrast, the North Sumatra and the Banten population had the highest genetic distance value (Figure 1). Furthermore, all of the swamp buffalo populations from seven provinces had a closer genetic distance.

\section{DISCUSSION}

This study on three loci in seven provincial, local swamp buffalo populations found two alleles in CSMM66 and ILSTS61. These two CSMM66 and ILSTS61 loci possessed a small allelic number compared to those swamp buffaloes from India (Mishra et al., 2015). A lower number of alleles identified from local swamp buffaloes in this study could be caused by inbreeding. This may be some possible condition, such

Table 1. Allele frequencies of Indonesian swamp buffaloes

\begin{tabular}{|c|c|c|c|c|c|c|c|c|c|}
\hline \multirow{2}{*}{ Locus } & \multirow{2}{*}{ Allele } & \multicolumn{8}{|c|}{ Population } \\
\hline & & 1 & 2 & 3 & 4 & 5 & 6 & 7 & 8 \\
\hline \multirow[t]{2}{*}{ CSSM66 } & A & 0.000 & 0.000 & 0.000 & 0.200 & 0.000 & 0.000 & 0.000 & 0.000 \\
\hline & B & 1.000 & 1.000 & 1.000 & 0.800 & 1.000 & 1.000 & 1.000 & 1.000 \\
\hline \multirow[t]{5}{*}{ ILSTS61 } & A & 0.220 & 0.200 & 0.390 & 0.000 & 0.000 & 0.040 & 0.030 & 0.000 \\
\hline & B & 0.150 & 0.400 & 0.450 & 0.020 & 0.280 & 0.250 & 0.100 & 1.000 \\
\hline & C & 0.600 & 0.370 & 0.130 & 0.430 & 0.340 & 0.150 & 0.170 & 0.000 \\
\hline & D & 0.015 & 0.015 & 0.030 & 0.100 & 0.200 & 0.180 & 0.480 & 0.000 \\
\hline & E & 0.015 & 0.015 & 0.000 & 0.450 & 0.180 & 0.380 & 0.220 & 0.000 \\
\hline \multirow[t]{2}{*}{ ILSTS17 } & A & 0.820 & 0.470 & 0.580 & 0.600 & 0.520 & 0.700 & 0.320 & 0.000 \\
\hline & B & 0.180 & 0.530 & 0.420 & 0.400 & 0.480 & 0.300 & 0.680 & 1.000 \\
\hline
\end{tabular}

Note: $1=$ Aceh; $2=$ North Sumatra; $3=$ Riau; 4= Banten; 5= Central Java; 6= West Nusa Tenggara; $7=$ South Sulawesi; $8=$ River Buffalo (North Sumatra) 
Table 2. Statistical summary based on population

\begin{tabular}{|c|c|c|c|c|c|c|}
\hline Population & Locus & $\mathrm{N}$ & $\mathrm{Na}$ & Ho & $\mathrm{He}$ & HW \\
\hline \multirow[t]{3}{*}{ Aceh } & CSMM66 & 30 & 1 & 0.000 & 0.000 & nd \\
\hline & ILSTS61 & 30 & 5 & 0.600 & 0.570 & $63.08^{* * *}$ \\
\hline & ILSTS17 & 30 & 2 & 0.100 & 0.340 & $14.92^{* * *}$ \\
\hline \multirow[t]{3}{*}{ North Sumatra } & CSMM66 & 30 & 1 & 0.000 & 0.000 & nd \\
\hline & ILSTS61 & 30 & 5 & 0.430 & 0.670 & $80.86^{* * *}$ \\
\hline & ILSTS17 & 30 & 1 & 0.000 & 0.000 & nd \\
\hline \multirow[t]{3}{*}{ Riau } & CSMM66 & 19 & 1 & 0.000 & 0.000 & nd \\
\hline & ILSTS61 & 19 & 4 & 0.890 & 0.000 & $7.91^{\mathrm{ns}}$ \\
\hline & ILSTS17 & 19 & 2 & 0.110 & 0.000 & $11.68^{* * *}$ \\
\hline \multirow[t]{3}{*}{ Banten } & CSMM66 & 30 & 2 & 0.000 & 0.000 & $30^{* * *}$ \\
\hline & ILSTS61 & 30 & 4 & 0.730 & 0.630 & $3.814 \mathrm{~ns}$ \\
\hline & ILSTS17 & 30 & 2 & 0.070 & 0.490 & $22.245^{* * *}$ \\
\hline \multirow[t]{3}{*}{ Central Java } & CSMM66 & 30 & 1 & 0.000 & 0.320 & nd \\
\hline & ILSTS61 & 30 & 4 & 0.630 & 0.610 & 10.99ns \\
\hline & ILSTS17 & 30 & 2 & 0.170 & 0.480 & $13.32^{* * *}$ \\
\hline \multirow[t]{3}{*}{ West Nusa Tenggara } & CSMM66 & 30 & 1 & 0.000 & 0.000 & nd \\
\hline & ILSTS61 & 30 & 5 & 0.730 & 0.740 & $17.70^{\text {ns }}$ \\
\hline & ILSTS17 & 30 & 2 & 0.070 & 0.500 & $21.232^{* * *}$ \\
\hline \multirow[t]{3}{*}{ South Sulawesi } & CSMM66 & 30 & 1 & 0.000 & 0.000 & nd \\
\hline & ILSTS61 & 30 & 5 & 0.670 & 0.730 & $23.202^{*}$ \\
\hline & ILSTS17 & 30 & 2 & 0.100 & 0.420 & $17.738^{* * *}$ \\
\hline \multirow[t]{3}{*}{ River Buffalo - North Sumatra } & CSMM66 & 12 & 1 & 0.000 & 0.000 & nd \\
\hline & ILSTS61 & 12 & 1 & 0.000 & 0.700 & nd \\
\hline & ILSTS17 & 12 & 1 & 0.000 & 0.430 & nd \\
\hline
\end{tabular}

Note: $\mathrm{n}=$ number of samples; $\mathrm{Na}=$ observed allele; $\mathrm{Ho}=$ observed heterozygosity; $\mathrm{He}=$ expected heterozygosity; $\mathrm{HW}=$ Hardy-Weinberg; $\mathrm{nd}=\mathrm{not}$ done; ns= not significant; ${ }^{*}=\mathrm{p}<0.05 ;{ }^{* *}=\mathrm{p}<0.01 ;{ }^{* * *}=\mathrm{p}<0.001$.

Table 3. Statistical summary based on three loci

\begin{tabular}{lccccc}
\hline Locus & Na & Ho & He & PIC & HW \\
\hline CSMM66 & 2 & 0.000 & 0.060 & 0.050 & nd \\
ILSTS61 & 5 & 0.620 & 0.770 & 0.740 & $* * *$ \\
ILSTS17 & 2 & 0.080 & 0.480 & 0.360 & $* * *$ \\
\hline
\end{tabular}

Note: $\mathrm{Na}=$ observed allele; $\mathrm{Ho}=$ observed heterozygosity; $\mathrm{He}=$ expected heterozygosity; $\mathrm{PIC}=$ polymorphism information content; $\mathrm{HW}=\mathrm{Hardy}-$ Weinberg; nd= not done; ${ }^{* * *}=\mathrm{p}<0.001$.

as due to the limited use of bulls in mating females or small effective population sizes of a certain population. One previous study reported a small effective population might cause inbreeding in local swamp buffalo in some areas in Banten (Praharani \& Sianturi, 2018). The number of individuals in a population was affecting the level of inbreeding, and a small population affected inbreeding depression (Pekkala et al., 2014). A study of genetic distance between swamp buffaloes in Indonesia was conducted by Anggraeni et al. (2011) with morphological analysis and found three clusters, i.e., cluster I (South Kalimantan, Aceh, and Banten), cluster II (South Sulawesi, Central Java, and North Sumatra), and cluster III (West Nusa Tenggara).

On the other hand, this study found two clusters, i.e., western cluster (Aceh, North Sumatra, and Riau) and eastern cluster (Banten, South Sulawesi, Central Java, and West Nusa Tenggara) (Figure 1). Furthermore, the variation of COI (Cytochrome Oxidase Subunit I) in Indonesia swamp buffalo showed three haplotypes among Indonesian swamp buffalo and two haplotypes found in buffalo from North Sumatra and Riau (Saputra et al., 2013). Based on the variation of COI gene proved two clusters i.e. cluster I (Sumatra Island) dan cluster II (Java Island, West Nusa Tenggara, and South Sulawesi).

This study found no correlation between molecular and morphological when compared with research conducted by Anggraeni et al. (2011). In contrast, another research found there was a correlation between the evolutionary rate of molecular and morphological (Seligmann, 2010). This is possible because of the small number of samples and loci. According to Arthofer et al. (2018), two highly polymorphic loci are visible in the flies population. However, in this study only found one high polymorphic locus of three loci across seven provincial, local buffalo populations.

Colli et al. (2018) explained buffaloes from China migrate from the Philippines to South Sulawesi, causing 
Table 4. Nei's genetics distance (Da) of Indonesian swamp buffalo

\begin{tabular}{cccccccc}
\hline Population & 2 & 3 & 4 & 5 & 6 & & 7 \\
\hline 1 & 0.038 & 0.061 & 0.151 & 0.097 & 0.098 & 0.158 & 0.396 \\
2 & & 0.021 & 0.168 & 0.068 & 0.086 & 0.114 & 0.213 \\
3 & & 0.240 & 0.120 & 0.111 & 0.149 & 0.227 \\
4 & & & 0.075 & 0.080 & 0.099 & 0.444 \\
5 & & & & 0.025 & 0.035 & 0.259 \\
6 & & & & & 0.047 & 0.317 \\
7 & & & & & & & 0.286 \\
\hline
\end{tabular}

Note: 1 = Aceh; $2=$ North Sumatra; $3=$ Riau; $4=$ Banten; $5=$ Central Java; $6=$ West Nusa Tenggara; 7 = South Sulawesi; $8=$ River Buffalo (North Sumatra).

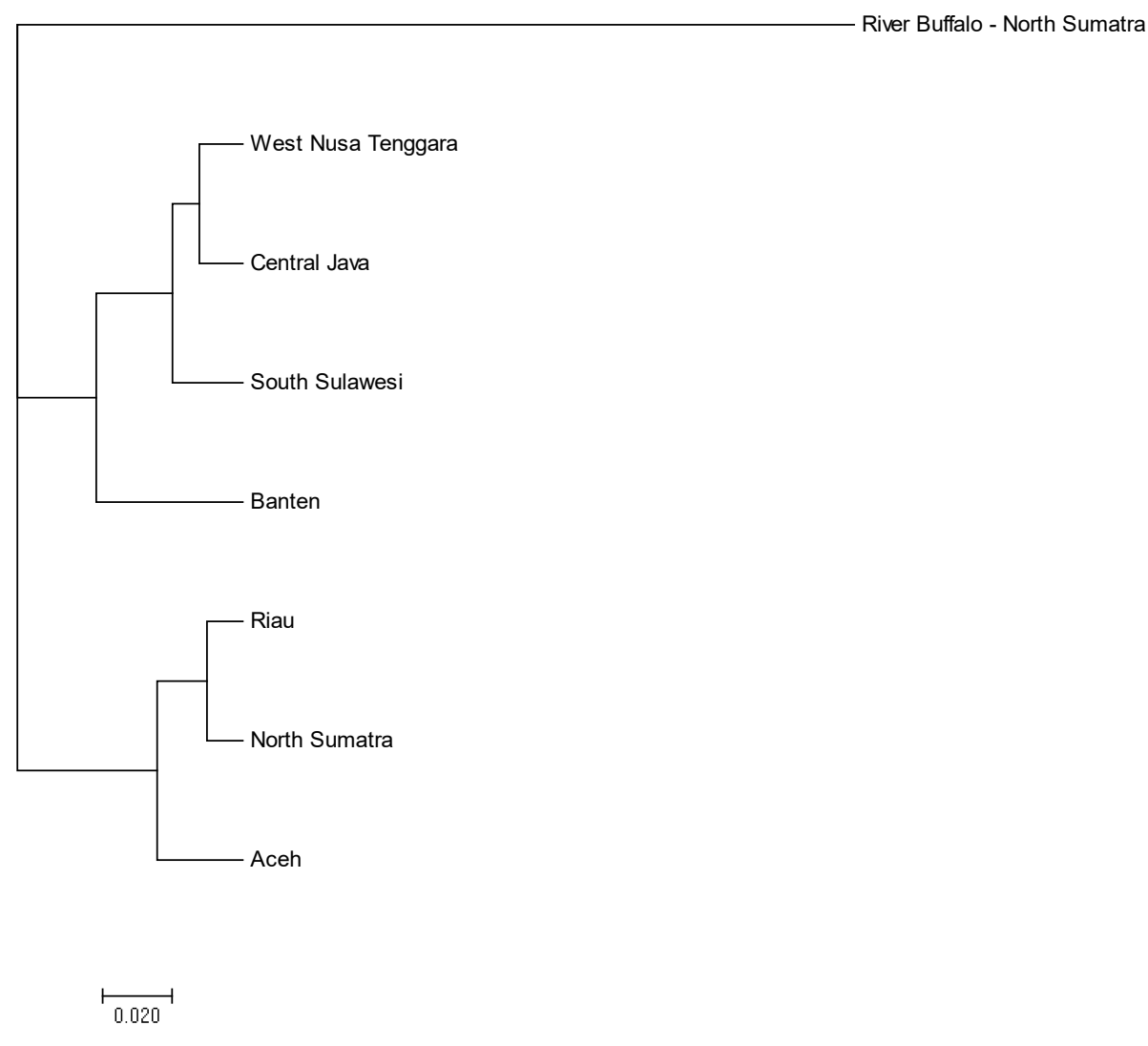

Figure 1. Dendrogram of Indonesian swamp buffalo using Unweighted Pair Group Method with Arithmetic Mean (UPGMA) method

more similarity between buffaloes in the Philippines and those in South Sulawesi. Rusdin et al. (2020) found two clusters of swamp buffaloes from South East Sulawesi that were different clusters from swamp buffaloes in Banten, West Nusa Tenggara, and Aceh. Moreover, it was reported that there was a genetic closeness in swamp buffaloes from the Philippines, South Sulawesi, and Southeast Sulawesi. Local swamp buffaloes from Sumatra, Java, and West Nusa Tenggara might be as the result of migration from the Thailand swamp buffaloes (Colli et al., 2018). In contrast, the dendrogram of this study showed that local buffaloes from Java and West Nusa Tenggara were different from those from Sumatra. According to Zhang et al. (2011), Indonesian buffaloes have similarities with buffaloes in South-western China, a location for the domestication of Lineage A (Yue et al., 2013). This proved that buffaloes in Indonesia were the result of the domestication of buffalo in China (Yue et al., 2013; Zhang et al., 2016). Based on the whole mitogenomes, the possibility of buffalo domestication in Southeast Asia occurred in the China-Vietnam border region (Wang et al., 2017).

The diversities of mtDNA and $\mathrm{Y}$ chromosome in swamp buffaloes were higher than those in river buffalo (Zhang et al., 2016). These three loci observed in this study were also observed by Kathiravan et al. (2009) in river buffalo in Marathwada, showing the high diversity of these three loci in river buffaloes from Marathwada. In contrast, the river buffaloes in North Sumatra had a low diversity (monomorphic). Inbreeding might be a possible cause of low diversity in river buffaloes from North Sumatra. The dendrogram in this study could distinguish between river buffalo (Bubalus bubalis) and swamp buffalo (Bubalus bubalis carabanesis) in the level of subspecies. 


\section{CONCLUSION}

The ILSTS61 locus was highly polymorphic for detecting genetic diversity among the Indonesian swamp buffaloes. This study found two clusters for Indonesian swamp buffalo. The western cluster consisted of Aceh, North Sumatra, and Riau, while the eastern cluster consisted of Banten, Central Java, South Sulawesi, and West Nusa Tenggara. These results will be useful for breeding and conservation management of Indonesian swamp buffaloes.

\section{CONFLICT OF INTEREST}

Jakaria and Cece Sumantri serve as editor of the Tropical Animal Science Journal, but have no role in the decision to publish this article. The Authors also declare that there is no conflict of interest with any financial, personal, or other relationships with other people or organizations related to the material discussed in the manuscript.

\section{REFERENCES}

Abdullah, M., H. Martojo, R. R. Noor, \& D. D. Solihin. 2012. Genetic characterization of the Aceh cattle using phenotypic, mitochondrial DNA of D-loop region and microsatellite DNA analyses. Reprod. Domest. Anim. 47:15-17. https://doi.org/10.1111/j.1439-0531.2011.01959.x

Agung, P. P., F. Saputra, W. A. Septian, Lusiana, M. S. A. Zein, S. Sulandari, S. Anwar, A. S. Wulandari, S. Said, \& B. Tappa. 2016. Study of genetic diversity among simmental cross cattle in West Sumatra based on microsatellite markers. Asian-Australas. J. Anim. Sci. 29:176-183. https://doi. org/10.5713/ajas.15.0155

Agung, P. P., F. Saputra, M. S. A Zein, A. S. Wulandari, W. P. B. Putra, S. Said, \& J. Jakaria. 2019. Genetic diversity of Indonesian cattle breeds based on microsatellite markers. Asian-Australas. J. Anim. Sci. 32:467-476. https://doi. org/10.5713/ajas.18.0283

Anggraeni, A., C. Sumantri, L. Praharani, \& E. Andreas. 2011. Genetic distance estimation of local swamp buffaloes through morphology analysis approach. Jurnal Ilmu Ternak dan Veteriner. 16:199-210. http://medpub.litbang. pertanian.go.id/index.php/jitv/article/view/614

Arthofer, W., C. Heussler, P. Krapf, B. C. Schlick-Steiner, \& F. M. Steiner. 2018. Identifying the minimum number of microsatellite loci needed to assess population genetic structure: A case study in fly culturing. Fly 12:13-22. https://doi. org/10.1080/19336934.2017.1396400

Barker, J. S. F., S. S. Moore, D. J. S. Hetzel, D. Evans, S. G. Tan, \& K. Byrne. 1997. Genetic diversity of Asian water buffalo (Bubalus bubalis): Microsatellite variation and a comparison with protein-coding loci. Anim. Genet. 28:103-115. https:// doi.org/10.1111/j.1365-2052.1997.00085.x

Byun, S. O., Q. Fang, H. Zhou, \& J. G. H. Hickford. 2009. An effective method for silver-staining DNA in large numbers of polyacrylamide gels. Anal. Biochem. 385:174-175. https://doi.org/10.1016/j.ab.2008.10.024

Colli, L., M. Milanesi, E. Vajana, D. Iamartino, L. Bomba, F. Puglisi, M. Del Corvo, E. L. Nicolazzi, S. S. E. Ahmed, J. R. V. Herrera et al. 2018. New insights on water buffalo genomic diversity and post-domestication migration routes from medium density SNP chip data. Front. Genet. 9:53 https://doi.org/10.3389/fgene.2018.00053
Jakaria, M. S. A. Zein, S. Sulandari, Subandriyo, \& Muladno. 2012. The use of microsatellite markers to study genetic diversity in Indonesian sheep. J. Indonesian Trop. Anim. Agric. 37:1-9. https://doi.org/10.14710/jitaa.37.1.1-9

Kalinowski, S. T., M. L. Taper, \& T. C. Marshall. 2007. Revising how the computer program CERVUS accommodates genotyping error increases success in paternity assignment. Mol. Ecol. 16:1099-1106. https://doi. org/10.1111/j.1365-294X.2007.03089.x

Kantanen, J., P. Løvendahl, E. Strandberg, E. Eythorsdottir, M. H. Li, A. Kettunen-Praebel, P. Berg, \& T. Meuwissen. 2015. Utilization of farm animal genetic resources in a changing agroecological environment in the Nordic countries. Front. Genet. 5:1-9. https://doi.org/10.3389/fgene.2015.00052

Kathiravan, P., B. P. Mishra, R. S. Kataria, \& D. K. Sadana. 2009. Evaluation of genetic architecture and mutation drift equilibrium of Marathwada buffalo population in Central India. Livest. Sci. 121:288-293. https://doi.org/10.1016/j. livsci.2008.06.023

Mishra, B. P., P. K. Dubey, B. Prakash, P. Kathiravan, S. Goyal, D. K. Sadana, G. C. Das, R. N. Goswami, V. Bhasin, B. K. Joshi, \& R. S. Kataria. 2015. Genetic analysis of river, swamp and hybrid buffaloes of north-east India throw new light on phylogeography of water buffalo (Bubalus bubalis). J. Anim. Breed. Genet. 132:454-466. https://doi. org/10.1111/jbg.12141

Peakall, R., \& P. E. Smouse. 2012. GenALEx 6.5: Genetic analysis in Excel. Population genetic software for teaching and research-an update. Bioinform. 28:2537-2539. https://doi. org/10.1093/bioinformatics/bts460

Pekkala, N., K. E. Knott, J. S. Kotiaho, K. Nissinen, \& M. Puurtinen. 2014. The effect of inbreeding rate on fitness, inbreeding depression and heterosis over a range of inbreeding coefficients. Evol. Appl. 7:1107-1119. https://doi. org/10.1111/eva.12145

Praharani, L., \& R. S. G. Sianturi. 2018. Inbreeding depression and alternative solution in buffaloes. Wartazoa 28:1-12. https://doi.org/10.14334/wartazoa.v28i1.1744

Rusdin, M., D. D. Solihin, A. Gunawan, C. Talib, \& C. Sumantri. 2020. Genetic variation of eight indonesian swamp-buffalo populations based on cytochrome $b$ gene marker. Trop. Anim. Sci. J. 43:1-10. https://doi.org/10.5398/ tasj.2020.43.1.1

Saputra, F., Jakaria, \& C. Sumantri. 2013. Genetic variation of mtDNA cytochrome oxidase subunit I (COI) in Local swamp buffaloes in Indonesia. Med. Pet. 36:165-170. https://doi.org/10.5398/medpet.2013.36.3.165

Seligmann, H. 2010. Positive correlations between molecular and morphological rates of evolution. J. Theor. Biol. 264:799-807. https://doi.org/10.1016/j.jtbi.2010.03.019

Takezaki, N., M. Nei, \& K. Tamura. 2010. POPTREE2: Software for constructing population trees from allele frequency data and computing other population statistics with windows interface. Mol. Biol. Evol. 27:747-752. https://doi. org $/ 10.1093 / \mathrm{molbev} / \mathrm{msp} 312$

Wang, S., N. Chen, M. R. Capodiferro, T. Zhang, H. Lancioni, H. Zhang, Y. Miao, V. Chanthakhoun, M. Wanapat, M. Yindee, Y. Zhang, H. Lu, L. Caporali, R. Dang, Y. Huang, X. Lan, M. Plath, H. Chen, J. A. Lenstra, A. Achilli \& C. Lei. 2017. Whole mitogenomes reveal the history of swamp buffalo: initially shaped by glacial periods and eventually modelled by domestication. Sci. Rep. 7: 4708. https://doi. org/10.1038/s41598-017-04830-2

Yue, X. P., R. Li, W. M. Xie, P. Xu, T. C. Chang, L. Liu, F. Cheng, R. F. Zhang, X. Y. Lan, H. Chen, \& C. Z. Lei. 2013. Phylogeography and domestication of Chinese swamp buffalo. PLoS ONE 8:1-13. https://doi.org/10.1371/journal. pone.0056552 
Zein, M., S. Sulandari, Muladno, Subandriyo, \& Riwantoro. 2012. Diversitas genetik dan hubungan kekerabatan kambing lokal Indonesia menggunakan marker DNA mikrosatelit. Jurnal Ilmu Ternak dan Veteriner 17:25-35.

Zhang, Y., D. Vankan, Y. Zhang, \& J. S. F. Barker. 2011. Genetic differentiation of water buffalo (Bubalus bubalis) populations in China, Nepal and south-east Asia: Inferences on the region of domestication of the swamp buffalo. Anim. Genet. 42:366-377. https://doi. org/10.1111/j.1365-2052.2010.02166.x

Zhang, Y., Y. Lu, M. Yindee, K. Y. Li, H. Y. Kuo, Y. T. Ju, S. Ye, M. O. Faruqoe, Q. Li, Y. Wang et al. 2016. Strong and stable geographic differentiation of swamp buffalo maternal and paternal lineages indicates domestication in the China/Indochina border region. Mol. Ecol. 25:1530-1550. https://doi.org/10.1111/mec.13518 